\title{
The Myths of a European Constitution
}

DOI: $10.35757 /$ CIV.2009.11.11

When the French rejected the Draft Treaty Establishing a Constitution for Europe a turning point was made in the debates on the future of the Old Continent. If the draft treaty prepared by the Convent is to be implemented, it should be first ratified by the 25 Member States. The first referendum took place in Spain on February $25^{\text {th }}, 2005$ and the results were positive; however, on May 29th 2005 the French rejected the project and the project treaty was similarly rejected by the Dutch on June $1^{\text {st }}, 2005$. Since then, journalists have refrained from commenting, and news concerning the treaty disappeared from the front pages. The Constitutional Treaty was then declared invalid and the question "why" was left unanswered. A project as ambitious as the establishing of a "European Constitution" should be preceded by serious discussion, and so it would perhaps be worthwhile to reflect on this issue and the serious crisis that followed the project's rejection.

A crucial issue at play here is the character of the European Constitution. The ample collection of European laws have become the normative basis for the functioning and existence of an enormous amount of different kinds of institutions. These laws particularly limit the power of State authority in the Member

Agnieszka Nogal is a doctor of philosophy and assistant professor at the Institute of Political Studies of the Polish Academy of Sciences in Warsaw (Philosophy of Politics Department) and in the Institute of Philosophy of the University of Warsaw. 
States. International law has taken on the character of external obligation, an issue that could be discussed elsewhere in the area of philosophical law, which precisely aims to cover this sphere of reality. In this article, I will present arguments for and against the description of a European order with reference to this concept. The aim is to present European constitutional ideas and an analysis of the Draft Treaty Establishing a Constitution for Europe from the point of view of the changes the European constitution has introduced into the discourse of philosophical law.

I have been investigating the problem of the European Constitution since I began working for the Institute of Political Studies of the Polish Academy of Sciences in 1994. The process which led to the ratification of the Polish Constitution was lively debated upon. After 1989, the political system changed, parliamentarian democracy demanded institutional reform in the system of law and analysis from a perspective of political theory. Much lively debate on the Polish constitution took place, and sometimes in the pages of "Civitas." While transformations in Central Europe were taking place, a process of unifying the law, of expanding the legal borders of community law, was being implemented in Western Europe. This unification process only began to affect Poland when the prospect of Poland's membership in the European Union drew close. A serious point of contention for political theorists, philosophers and lawyers was the concrete regulations in the European Law.

A new order in Europe was forming before our very eyes, in both the legal and the political order. As Urlich K. Preuss notes, one of the most important steps on the road to the transformation of the European Community in the European Union was the establishing of Articles 8-8e of the Treaty of the European Union on European citizenship. ${ }^{1}$ Joseph Weiler referred to the declaration of

1 U.K. Preuss: Two Challenges to European Citizenship, in. R. Bellamy, D. Castiglione (eds.): Constitutionalism in Transformation: European and Theoretical Perspectives, Blackwell, Oxford 1986, p. 122 . 
the European Tribunal, which states that "the European Economic Community constitutes a new legal order of international law for the benefit of which, albeit within limited fields, and the subjects of which comprise not only the Member States but also their nationals." ${ }^{2}$

Originally European cooperation was strictly international. After World War II, the Western States recognized the need for collaboration on the one hand based on a liberal system of values toward an economy contrary to the system elected in the Eastern Bloc, and on the other hand, a multiparty political party system of government based on a pluralism of world views, which in turn was opposed to the one-party system, aimed at the implementation of the one true political vision. The basis of European economic collaboration was the liberal principle of the free market, which made bigger and better-organized markets more competitive than the markets under government protection.

The symbolic dimension of European integration, economically and politically, was the announcement of the Schuman Declaration, which has been recognized as the beginning of the history of European Communities. When World War II ended, Jean Monnet presented a proposal for a modernization and economic progress plan to the French Government. As the commissioner to planning affairs, Monet proposed the founding of the European Community, whose conception was presented on May 9, 1950 by Robert Schuman, the Minister of Foreign Affairs. The Schuman Declaration proposed that the coal and steel industries be removed from State regulations and placed under an autonomous administration, under a specially commissioned body for that purpose, known as the "High Authority." This initiative was meant to create Franco-German control over coal and steel production. Schuman declares:

2 Case 26/62 N.V. Algemene Transportän Expeditie Oderneming Van Gend \& Loos $v$. Nederlandse administratie der belastingen 1963 (http://eurlex.europa.eu/LexUriServ/Lex UriServ.do?uri=CELEX:61962J0026:EN:HTML) 
By pooling basic production and by instituting a new High Authority, whose decisions will bind France, Germany and other member countries, this proposal will lead to the realization of the first concrete foundation of a European federation indispensable to the preservation of peace. ${ }^{3}$

These uniform liberal market principles were to the strengthen the growth of both production and the competitiveness of the Western European Countries with respect to the Eastern European Market; they were also meant to facilitate the establishment of unified regulations in crucial sectors, therefore ultimately leading to the progress of peace and stabilization and the improvement of the standard of living. ${ }^{4}$ Aside from the justified reference to the idea of prosperity, which was to serve peace, it was not by accident that the common market was only concerned with the coal and steel industries, fields directly related to military potential. France and Germany, who had been warring against each other for many years, resolved to submit this crucial sector to the control of an independent organ. At that time, this meant a restriction of a significant amount of sovereignty to declare war or peace. Shortly afterwards, Belgium, Luxembourg and the Netherlands willingly acceded to this proposal of collaboration.

Analyzing this example of the first Community, one can observe a characteristic feature of later progress, namely the predominance of economic cooperation over political. In the debates that surrounded the Schuman Declaration, much reference was made to the need to build a peaceful territory, where democratic systems could flourish. At the same time, it was believed that that the best way to create such a territory was through the economic cooperation of states, the market's embracing of greater military significance, the growth of effective productivity, the multiplication of wealth, and the improvement of the standard of living.

\footnotetext{
3 http://europa.eu/abc/symbols/9-may/decl_en.htm

4 C. Mik: Europejskie Prawo Wspólnotowe. Zagadnienia teorii i praktyki [European Common Law. Theoretical and Practical Aspects], Wydawnictwo C.H. Beck, Warszawa 2000, s. 32.
} 
The liberalization of the market turned out to be effective; various other Communities were nominated through powerful international treaties. In 1962 the Parliamentarian Unit was nominated and named the European Parliament. At that time, more efforts were made to strengthen the bonds and uniformity of specific institutions of the Communities. Five years later the Merger Treaty was implemented, by virtue of which a single organ was created: the Council, or Commission. Along with the European Parliament and the Tribunal of Justice, they comprised one of the institutional pillars of the Communities.

These Communities were granted the right to establish articles and shape the law, which would be directly applicable to their citizens. In this way, via a judgment made in 1962 on the Van Gend $\&$ Loos Case, the European Economic Community was acknowledged as an organ competent to constitute a new international order, which would not only influence the Member States, but their nationals as well. ${ }^{5}$ European law from then on was acknowledged as a precedent to all the internal laws of the Member States. The characteristic feature of sovereignty, the competence to establish laws, was partly passed on to the supranational institution. In justification of this solution, reference was made to the universally accepted principle of sovereignty. Since the Treaty obliged the nations to the common implementation of clearly identified aims and to the establishment of particular institutions to which legal power had been granted, the power of these institutions was directly transferred from the will of the nations. This, therefore, is the suprapower over particular institutions, which in turn have become internal elements of political order. The main principle of internal law is that of respecting contracts. Since the Member States have bound themselves by law, it should be acknowledged therefore that the citizens of those countries and all institutions are likewise bound by law, and they should be subjugated by the community law.

\footnotetext{
${ }_{5}$ Case 26/62 N.V. Algemene Transportäen Expeditie... .
} 
After the ratification of the Maastricht Treaty on February $7^{\text {th }}$, 1992, a common currency was introduced and a new vision of closer collaboration was presented. The next feature of sovereignty, the right to mint coins, was transferred to a supranational institution. This provoked a wave of competency conflicts, in which the German and Federal Constitutional Court took active part in defending the autonomy of German codified written documents over the community law, by noting that the States should be "Masters of Treaties." Since then, issues concerning competencies have remained unresolved.

The second axiological basis of the European Community, aside from a common market and the aim of material prosperity, was the issue of human rights. These laws have been the subject of international protection only since World War II, when the United Nations Organization declared one of its aims to be the support and encouragement of all countries to respect the human rights of all people, and not only their own citizens, regardless of race, sex, language or religion. The Universal Declaration of Human Rights, which was adopted and proclaimed by the General Assembly of the United Nations on December $10^{\text {th }}$, 1948, was a classical element of international public law, on which Thomas Hobbes had written a great deal. The goodwill of all is necessary to observe this law. The Declaration of Human Rights, however, also inspired the European Convention of Human Rights, proclaimed two years later, which became a "real" legally binding document.

The European Convention on Human Rights and Fundamental Freedoms was drawn up in Rome in 1950 and accepted by the Council of Europe. This was the first institutionally effective mechanism for the defense of human rights on the supranational level. An autonomous body known as the European Tribunal on Human Rights supervised the implementation of the Convention, and from then on the Tribunal took charge of complaints raised

Manfred Brunner and others $v$. The European Union Treaty (Cases 2 BvR 2134/92 \& 2159/92), "Common Market Law Reports" 1994, January $11^{\text {th }}$, p. 60. 
both by private individuals and states toward other states. The Convention contained a first-generation lecture on human rights. By acknowledging the right to individually stand before a court, the legal situation of citizens in relation to state authorities changed drastically. Citizens gained the capacity to sue their own state authorities if their human rights were violated. Another feature of sovereignty, the right of the national supreme courts to act as the Court of Final Instance, was thus restricted. By virtue of the judicial jurisdiction of the Tribunal Court in Strasbourg, the internal laws of signatory states also evolved, which in turn influenced the unification of European standards in this sphere.

The progress of European law was both a long-term and a multi-thematic process. The collection of legal acts and further expanded judicial jurisdictions in the last fifty years added to the already thick volumes. Its subsequent pages were the fruit of legal and political decisions. Legal debates took place between the Constitutional Tribunals and the European Tribunal of Justice, while political discussions were the subject of international conferences and further treaties. Many stipulations were made as to the openness of these processes: The European Tribunal of Justice often dictated the conditions of cooperation to its partners, while European Law was gradually introduced by internal institutions and the active participation was often demanded of these institutions. They would not have functioned were it not for national courts and tribunals, which in turn implemented their resolutions. Debates in international conferences often led to the introduction of legal acts, the fruit of negotiations and compromises, in which sides of differing potentials could not match their opponents in force of argumentation. The publishing and opening of debates, a radical means of change, shifted decision-making into the arena of international conferences, and the made a move toward the building of a coherent constitutional future for an expanded EU. 
An extreme alternative for international conferences and debates between both tribunals was the old "Philadelphian" dream of proclaiming a "United States of Europe." This was particularly attractive for the post-war generation, for whom hopes of a peaceful and safe future were tied to the vision of a united Europe. A similar idea was put forward by Altiero Spinelli in his project for building a European federalism. As a result of this initiative, the European Parliament accepted a document, calling it cautiously the Draft of the Treaty. A few years later, in 1989, a constitutional model was approved and accepted by Italy in a consulting referendum, which became a clear impulse for the European Parliament. ${ }^{7}$ On December 12, 1999 a version of this text was prepared, and although it was not meant to be strictly constitutional, it was presented as the final version of the Constitutional Project. The actions taken by the Parliament, however, proved fruitless. A few days after the approval of Parliament's constitutional resolutions, international negotiations began, and later ended with the signing of the Maastricht Treaty. From that moment onward, the idea of a "Constitution of a United States of Europe" was dubbed the utopian vision of intellectuals, and if any projects of unifying the "States" of Europe arose, they were formulated much more cautiously.

However, because of the increasing competencies of supranational institutions and the growing abundance of judicial jurisdictions, serious law-related philosophical and theoretical issues were raised. From the classical point of view, law and constitution were only related to the states. Here, however, judging by our new experiences, regulations were created and made obligatory not only for states as international contracts, but for citizens as well. Citizens, therefore, could directly stand before the Tribunal in Strasbourg and win a case against their own state.

\footnotetext{
7 B. De Witte: The Closest Thing to a Constitutional Conversation in Europe: The Semi-Permanent Treaty Revision Process, in: P. Beaumont, C. Lyons, N. Walker (eds.): Convergence and Divergence in European Public Law, Hart Publishing, Oxford 2002, p. 55.
} 
Law theorists were faced with a serious problem. A solution could be found either by applying a new reality to classical concepts or by trying to find new, theoretical solutions. In the first case, one could say that no European order of supranational law existed, that we were dealing with a classical issue of international law. If this were the case, talk of constitutional restrictions or constitutional order would be irrelevant, for we are dealing with an idea of a constitution reserved only for the defining of national harmony and order, while the idea of Europe would be relegated to a certain sphere of international cooperation. In this case, the idea of a confederation may arise, that is, the relationship of state created for a specific purpose. In a confederational kind of relationship, States maintain complete international autonomy.

Another approach based on the classical democratic theory of a legal state is acknowledging the introduction of modification in the field of the legal functioning and its accompanying postulates, so that whatever goes beyond the competencies of the State can transformed into a kind of federation along with an appropriate conceptual instrument for the federational structure. Behind such a solution lies the philosophical myth of creating a European State, for which "a federation" is only a softer equivalent to define its internal structure. It is within this tendency that the abovediscussed efforts of the European Parliament find themselves.

A third approach would be the attempt of going beyond the language of national state theory and finding a description for the European political reality in its modified categories, one which would aptly describe its character. This solution, practically unknown in Poland, was postulated by Joseph Weiler, the author of a work now considered a classic: The Constitution of Europe: "Do the New Clothes Have an Emperor?" and Other Essays on European Integration ${ }^{8}$. According to the author, the constitutional

H.H. Weiler: The Constitution of Europe: Do the New Clothes Have and Emperor?: and Other Essays on European Integration. Cambridge University Press, Cambridge 1999. 
architecture of Europe already exists, and has been created by the accumulated legal documents of the Community. Behind such a stand lies the thesis of a myth of Europe as an area of accepted solutions, which in turn serve the Member States and are therefore commonly implemented by them.

Debates on the draft of the Treaty Establishing a Constitution for Europe took place in Poland; however, they completely overlooked the philosophical debates that accompanied the stages of the transformation of international into a supranational law. By looking at the text in isolation from these debates which are part of it, it could be perceived as a clear act of rejecting the model of State in favor of a federation, as a guarantee of preserving the State's sovereignty. It would be worth recalling that, at that same time, the Commissioner to the Affairs of Regional Politics suggested adding a statement of procedure for leaving the European Union to guarantee State sovereignty; paradoxically, this article provoked much debate in Western Europe. It was acknowledged that there was no need to include an article formalizing the need to leave the European Union, since the Union is based on the goodwill of the States, and the lack of such goodwill would suffice to leave the organization. This sphere of debate on the Constitution demonstrated that this issue, like many others, was practically unknown to the Polish public.

The political debates that preceded the preparations of the Treaty draft were accompanied by the public appearances of Joschka Fischer and Lionel Jospin in 2000. At this time, they delivered a speech in which they demonstrated the need for a written European constitution. Politicians tend to declare their programs, especially on such sensitive issues as the supranational Constitution, only when they can rely on a warm reception by the electorate. I am not, by any means, trying to accuse them of Machiavellian strategy, I am only trying to make the simple statement that any political declaration requires the appropriate climate. In referring to the European constitution, therefore, 
Jospin and Fischer were not speaking as prophets. While remaining politicians, they were addressing a concrete audience. Joschke Fischer formulated an alternative: it was possible that in the future, in his opinion, the Union would be expanded, which would be accompanied by a necessary constitutionalization or maintenance of the form of the Community then applied.

A special Convent was to prepare the Constitution. Let us recall very briefly its genesis: The first step toward the writing of a formal Constitution was the nomination of a special body, which was to be in charge of preparing the Charter of Human Rights. Following the project by Deirdre Cutin, a group composed of members of the European Parliament, national parliaments, the Commission and other state representatives was to prepare the Charter of Fundamental Human Rights. This same group called itself as the Convention, although no one officially called them a constitutional convention. Nonetheless, many followed their project with great hope, filled with the voices of those who were supporters of the federal project of deep supranational integration. It has to be acknowledged that the relatively limited area of competencies was not recognized by the governments of the States. Finally, the Charter of Fundamental Human Rights was signed in Venice on December $7^{\text {th }} 2000$. Its acceptance, however, was a disappointment for the "federalists," as it turned out that the fruits of Convent's work had to be accepted by the States, which only proved their dominating role. The Charter never became a legally obliging document, while the limits of its regulations only slightly expanded the juridical practice.

On the basis of this alone, one could draw the simple conclusion that the attempt to make the European Constitution a step toward replacing the States with a federation was not legitimate, although the changes made by the Convent were undoubtedly aimed as moving toward a Federal Europe. However, this would only have been possible under previously established limitations. 
After the calendar of expansion was accepted (March 1, 2002) the Convent resumed its work. The task that they had before them was to prepare a uniform document which constituted a supranational political order. The federalists put great hope in the nomination of the Convent; however, its plan of action already demonstrated the impossibility creating a revolutionary document. The efforts of the Convent were finalized in the safe form of the "Treaty for a Constitution." The changes introduced were likewise limited in relation to the prior legal status. Eleven working groups worked on the reconstruction of the legal status, they proposed modifications which were to simplify existing solutions, to provide a more precise distribution of competencies and a definition of the legal status of the Charter of Basic Human Rights, and to work on the introduction of national parliaments into the institutional architecture of the European Union. Were those who worked on the draft treaty inspired by any coherent vision of the future Europe? Did they reflect on what European myth the Constitution would create? Unfortunately, they did not.

The language of the prepared project turned out to be incoherent. This could be clearly seen in the Preamble. The Convent originally proposed the inclusion of a statement of how the European cultural heritage draws from the heritage of ancient Greek and the Age of Enlightenment. Such a solution, however, met with criticism. Many demanded that a clause on the invocatio Dei and on religion be included in order to stress that therein lay the roots of European identity; this in turn resulted in reference to the cultural, religious and humanist heritage. Universal values and the rights of man were to be seen as values that sprung from this heritage. Europe, united after bitter experiences, according to the Preamble, was to aim for peace, justice and solidarity in the world. Nations proud of their national identities were to form a common future. The Preamble could suggest that the document was a step towards a European Federation, that could bind a common identity, a common historical experience, and 
a common axiology of human rights. A reading of the Preamble, much like the Charter of Fundamental Human Rights, without taking into consideration the rest of the document and the context of its genesis, would indicate the connection of the draft treaty to the philosophical myth of a federal Europe. This provoked a great deal of strong criticism. In Poland we saw it as a threat to our sovereignty, and the Union's acceptance of national state competencies.

The next fragment of the Draft Treaty Establishing a Constitution, which was acknowledged as a step towards federation, was the Charter of Fundamental Human Rights. A rough analysis, however, of both the Charter of Rights and its functioning within the European legal order after its later incorporation into binding legal acts shows that this is not a document which would revolutionize the situation of citizens. Despite this fact, the regulation of the Charter goes beyond the laws accepted in the presently obliging Convention; however, most of it belongs to the jurisdictional competencies of the Tribunal of Justice. Those, however, which go beyond the present limitations will be treated as rules that simply determine the direction of forthcoming legislative actions. Apart from that, all fall within the bounds of the European Union, they do not influence the situation of its citizens and their rights and obligations to their States. Only forthcoming legislative and judicial practice will give the Charter true significance.

The Charter also includes laws which go beyond the competencies of the Union; it mentions the right to social security and the right to social help (Article I.34), the right to health care (Article I.35), and the right to access services of general economic interest, though the Union does not have the competency to act in this area. ${ }^{9}$ The statement on free education (Article I.14.2) likewise refers to a field which is beyond the Union's competency, for it

9 Cf. N. Walker: The Charter of Fundamental Rights of the European Union: Legal, Symbolic and Constitutional Implications, in: P.J. Culle, P.A. Zerkavis (eds.): The Post-Nice Process: Towards a European Constitution?, Nomos Verlag, Baden-Baden 2002, p. 8. 
does not influence the manner in which the State educational systems function. Apart from that, the eighteenth-century vision of individual rights is broken down into minority rights here, and therefore into collective rights.

The principle of equality between men and women is strengthened in Article I.23. This article, however, opens the way to the legal acceptance of legally affirmative actions. The principle of equality was acknowledged as not contradicting parity, to the advantage of the sex which underrepresented in society.

Will including the document in the constitution lead to any revolutionary results? This is unlikely, though it would be hard not to notice the fact that the development and promotion of uniform standards in the area of defense of human rights may be a step towards a European federation.

This definition of the Union's competencies could also lead to the conclusion that the constitutional draft is realizing a model of a federal Europe. Instead of accepting the division into earlier approved pillars, the Draft Treaty organizes the EU's activities according to a division of competencies. A differentiation has been made here between manners of exclusive competence, fields in which institutions are in charge, and inclusive competencies, in which the competencies of the Union intertwine with those of the States.

According to Article I.11.2, the legislative precedence of the Union should in principle grant shared competencies to both the Member States and institutions of the Union, while according to the project they both have the right to regulate their territories.

In the other disciplines, where the States remained only legislative creators, an inspiring and coordinating role was planned for the Union.

The economic and employment policies were especially mentioned in Article I.11.3. In these spheres legislative competencies remained in the hands of the Member States, while the Union was only to promote and coordinate the initiatives of the States. 
Common foreign and defense policies were likewise differentiated, by including work involved in building a common security policy. In Article I.11.4 legislative competencies remained within the States, and the Union was only to determine and introduce their common initiatives in these fields.

Other areas of study and investigation and the exploration of outer space were likewise enumerated, and the Union was to take the necessary steps to prepare and implement programs in these fields. However, these decisions were not to limit or restrict the Member States.

The actions taken by the European Union in these enumerated fields were to consist in supporting, coordinating and completing the tasks done by the Member States, but without violating their competencies. It seems that this was to emphasize the political role of cooperation in areas where the consequences of the common market are felt, areas which influence the form the market takes on (such as economic policy and employment policy), and in the sphere of international relations.

The Union took the form which more resembled a traditional division of power because of the division of competencies and the Draft Treaty. The Commission was to perform the executive function, and the Council and Parliament, the legislative function. However, two elements remained present: the intergovernmental, which was represented by the European Council and Council, and the supranational, which was represented by the Commission.

The next step towards a federation of Europe was the expansion of the scope of issues that was to be encompassed by the qualified majority voting, and the introduction of the principle of double majority. European citizens were to have a greater impact on the direction of the community's progress, with no intervention from the national juries. The aspiration towards the federalization of Europe was met however with a great deal of opposition, especially in the new Member States. With the increased competencies of institutions representing European citizens, the demographic 
factor became more dominant, and the roles of States with the greatest populations increased.

In the constitutional draft another axiological order was present, one in which the political subject was not only the individual, but also social groups of various kinds of communities, including nations. Here one can find an echo of the myth of Europe as a territory of reconciled solutions between different national communities. Article I.3.3 paragraph 4 declares that "The Union shall respect its rich cultural and linguistic diversity, and shall ensure that Europe's cultural heritage is safeguarded and enhanced." In Article IV-1 we read, "The motto of the Union shall be: United in diversity."

The principle of subsidiarity which organizes the division of competencies makes clear reference to the communitarian vision of the Union, which in acting within its competencies, acts then on common aims which cannot be reached by communities of lower instance, that is, by local and State communities. The Draft Treaty Establishing a Constitution for Europe likewise makes reference to the principle of conferred competency. In Article I.1 we read, "Reflecting the will of the citizens and States of Europe to build a common future, this Constitution establishes the European Union, on which the Member States confer competencies to attain objectives they have in common." The principle of conferred competence clearly shows the primacy of the national communities, which pass their will expressed in the treaties only as concrete competencies, defining common objectives and the nomination of institutions to realize these objectives. Aside from these entitlements and qualifications, the Union cannot take any regulatory actions. The field in which the Member States have recognized the need for cooperation is currently limited to the common monetary policy (with reference to those States which have accepted the common currency), common trade policies, customs union and the regulation of fisheries. However, the area of these conferred competencies is expanding with the passing of time. 
A reading of the Draft Treaty for Establishing a Constitution for Europe firstly leads us to the conclusion that it was faithful to the prior treaty resolutions. Secondly, in analyzing the changes introduced, one cannot sketch out a coherent myth of Europe. On the contrary, one can only find the myth of a federation, and the myth of Europe as a territory of common will amongst communities of states. While it is true that the trend toward a federation is present, its advantages have not removed the friction tangible in the previous European documents.

The conflict of these two visions of Europe, which brought with it two different and opposing perceptions of Europe's development, was, in my opinion, the most essential aspect, though it often was not articulated. The supporters of the federalist project accused their adversaries of nationalism and xenophobia. Those, on the other hand, who thought within the categories of a national state community showed numerous threats which could be brought about by European institutions overstepping their roles. Unfortunately, in the process of constitutionalizing Europe there were no open debates. This is something which is rather unfortunate. Concrete solutions have been proposed by politicians and experts working on specialist problems.

The authors of the Draft Treaty Establishing a Constitution for Europe were not in a position to provide a clear formulation of a constitutional framework. Attempts at consensual treaty solutions were made supporting the decision toward serving majority issues and thinking in terms of a federal Europe. This, however, proved to be neither clear nor obvious, and it was not put under discussion.

The expanding of the principle of the qualified majority voting became ignited debate in Poland. This in turn led to an essentially controversial element in both of the European myths, namely: Does a European nation (demos) exist (and should it exist)? For within a relatively homogenous people, a majority government limited by minority rights could exist. Faced with the lack of 
a European nation, the requirement that the people should accept the principle of the qualified majority vote could not find any support. The step toward majority voting was unanimously rejected by representatives of the Polish government. An interpreter of the constitutional debates, Joseph Weiler, concluded that, with the lack of a political nation, demanding an application of the majority vote is much like asking the Danes to be under the majority legislative process in the Bundestag, where their right to vote would be guaranteed. ${ }^{10}$

An analysis of the rejection of the draft treaty, particularly of its shortcomings, could lead us then to the category of the people or the political community. The question of a constitution and its character should have been formulated in such a manner so as to devote attention to the subject of political activities. Should we, therefore, avoid the question about the constitution or the constitutional treaty, and above all, should we ask whose power is being dealt with here? What is the contemporary political community, where and at which level should we start seeking it, in which direction should it evolve, which changes should be deemed necessary and worth investing shared effort ...

The philosophical myth of a European federation, of which, for example, Jürgen Habermas is an enthusiastic supporter, presupposes the possibility of shaping a political community on the supranational level. The myth of Europe as a territory of reconciled solutions, which would primarily serve the Member States, demonstrates the lack of a European nation, yet it also warns us against its "construction." It is precisely the variety of national communities that enriches Europe and affects the dynamic shaping of the territory of consensus. If the debates surrounding the Constitution should go beyond a legal and political context, they should attempt to address these issues. The Draft of the Treaty Establishing a Constitution was unable to put forward

${ }^{10}$ Cited in R. Bellamy and D. Castiglione: Legitimizing the Euro-Polity and its „Regime”, „The Normative Twin EU Studies: European Journal of Political Theory” 2003, no. 2 (1), p. 26. 
any answers. It may have been good for the philosophers that the Constitution was not implemented. This allows us to reflect peacefully and deliberate upon our vision of Europeinstead of once again explaining something which has hastily been made a reality.

Translated by Clarinda Calma

First edition: Mity europejskiej konstytucji, "Civitas. Studia z Filozofii Polityki" 2006, vol. 9, pp. 80-97. 